\title{
Effect of Leverage on Performance of Non-financial Firms Listed at the Nairobi Securities Exchange
}

\author{
Mukaria Henry Kimathi", Mugenda Nebat Galo, Akenga Grace Melissa
}

Faculty of Business Studies, Chuka University, Chuka, Kenya

\section{Email address:}

henrykimathi@gmail.com (M. H. Kimathi)

\section{To cite this article:}

Mukaria Henry Kimathi, Mugenda Nebat Galo, Akenga Grace Melissa. Effect of Leverage on Performance of Non-financial Firms Listed at the Nairobi Securities Exchange. Journal of Finance and Accounting. Vol. 3, No. 5, 2015, pp. 132-139. doi: 10.11648/j.jfa.20150305.14

\begin{abstract}
Managers strive to maximise shareholder wealth by making rational financing decisions regarding optimal capital structure which would minimise its cost of capital. In attempt to magnify the return to shareholders, managers employ the use of debt. When excessive debt financing is employed by a firm, it increases the cost of financing and the financial risk of the firm leading to decreasing the return on equity as a result of financial distress. Do the various debt equity ratio levels lead to different financial performance when compared for high levered and low levered firm, high growth and low growth firm or large and small firms? A causal research design was used to establish the cause and effect relationship between financial leverage and the financial performance of the firms. The target population was 61listed firms on the Nairobi securities exchange by December 2013.Purposive sampling was used to select 38 non-financial companies. Financial companies were eliminated because the company's capital structures have specific characteristics affected by industry regulatory requirements. Secondary data was obtained from published financial statements of the sampled companies for the six year period from 2008 to 2013. Ordinary Least Square method was used to establish the cause effect relationship among variables; Hypotheses were tested at 5\% significance level using t-statistic. The study found that there was no significant difference in financial performance between highly levered and lowly levered firms and that there existed a negative relationship between Leverage and firm's performance. There were also no significant differences in financial performance between high growth levered firms and low growth levered firms and that there existed a negative relationship between a firm's growth opportunity and financial leverage ratio. There was no significant difference in financial performance between large levered firms and small levered firms. The findings of this study may act as a policy guideline to finance managers involved in managing firms on the contribution of financial leverage and its association with return on equity to maximise shareholder wealth.
\end{abstract}

Keywords: Leverage, Performance, Growth Firms, Levered Firms, Large Firms, Liquidity

\section{Introduction}

An important objective of a firm is to maximise shareholder wealth. Managers strive to achieve this objective by making rational financing decisions regarding optimal capital structure which would minimise its cost of capital. Less than optimal capital structure decisions can lead to an increased cost of capital and result in reduction of shareholders wealth. According to Gitman (2009), the value of a firm is maximised when its cost of capital is minimized. The capital structure puzzle involves a firm's decision that managers make a choice of ideal proportion of debt and equity that will minimize the firms cost of capital which is the optimal capital structure and in return maximise shareholder's return. The capital structure of a firm consists of mix of internal and external sources of funds use to finance firms' asset. Financial leverage is the use of debt in a company's financial structure for magnification of earnings (Pandey, 2005).A firmapply leverage with an objective of maximising the potential return of shareholders wealth. If a firm uses debts it has to pay some interest in exchange for the use of these resources. The more debt ratios rise, the more financial risk increases and the debt costs increase accordingly. The increased cost reduces the limit of profitability resulting from debt financing. A financial performance measure provides a valuable tool to stakeholders to evaluate the past financial performance and the current position of a firm. 
Shareholders return is reflected by a measure of how well a firm can use its' assets from its' primary business to generate revenues (Abor, 2005). Managers should emphasize on the optimum level of capital structure and efficient utilization and allocation of resources in order to increase the company's financial performance based on capital structure. When corporations decide on the use of debt finance, they are reallocating some expected future cash flows away from equity claimants in exchange for cash up front. Jensen (1986), debt can therefore reduce excessive consumption of perquisites because creditors demand annual payments on the outstanding loans. The stock market's perception of what constitutes a normal capital structure may punish those firms that have a capital structure that deviates from the norm (Baker and Wurgler, 2002). The asymmetric information model assumes that managers generally have better information about their firm's than outside investors. Well-informed insiders tend to convey the firm's positive information to the poorly informed outsiders to enhance the firm's performance. Debt signals to the capital market investors that the issuing firm is a high performance firm (Myers and Majluf, 1984).

Nairobi Securities Exchange (NSE) is the principal stock exchange of Kenya. NSE is licensed by Capital Market Authority (CMA) with its main obligation to regulate the security market and ensure trading of securities by bringing together borrowers and investors at low cost. Regulation of quoted firms is achieved by ensuring that firms stand by the rules and regulations set by providing their periodic performance reports. As a capital market institution, the Securities Exchange plays an important role in the process of economic development (www.nse.co.ke, 2014). It helps mobilize domestic savings thereby bringing about the reallocation of financial resources from dormant to active agents hence the Nairobi Securities Exchange becomes a point of attention for studies.

Abor (2005) argues that the optimal capital structure maximizes profitability and shareholders' wealth. However, the effect of financial leverage on profitability may be positive or negative based on the productivity in the use of debt financing. A positive relation indicates that when the firms depend on debt as much as firms needs, it will lead to enhance their performance (Aburub, 2012). This explains why a financial manager depends on debt as financing source more than owner equity. Khan (2012) indicates that, if the effective debt ratio is exceeded, the firm would face financial difficulties and the positive effect of financial leverage might turn to negative. Since the capital structure decision is very critical as a determinant of shareholders return, it was necessary to determine the precise relationship between capital structure based on leverage level, firm size and growth rate and financial performance in attempting to maximize shareholders wealth. The study therefore sought to address the question: what is the impact of leverage level on the performance of firms listed at Nairobi securities exchange?

\section{Review of Literature}

\subsection{Theoretical Framework}

Modigliani \& Miller (1958) assumes that financing decisions do not matter in perfect capital markets. The level of debt in the firm's capital structure would have no impact on the firm's value, performance and shareholders' value. Modigliani and Miller first preposition was that the market value of any firm is independent of its capital structure and is given by capitalizing its expected return at the rate appropriate to its class. Modigliani and Miller second preposition was that the expected yield of a share of stock is equal to the appropriate capitalization rate for an equity stream in the same risk class, plus a premium related to financial risk equal to the debt-equity ratio times the spread between the capitalization rate and the cost of debt. The preposition indicated that as debt-equity ratio increases, the expected return on equity will also increase as long as the debt was risk-free. However as leverage increases the risk of debt, the debt holders also require more return on their debt and this causes the increase in the return on equity to slow down.

Modigliani and Miller (1963) expanded their work and incorporated corporate taxes to the model of corporate valuation by assuming that the value of a levered firm equals the value of an un-levered firm plus a premium derived by discounting to perpetuity the stream of tax savings which is applicable so long as the firm has sufficient taxable capacity. Because interest expenses are tax-deductible but dividends are not, this encourages firms to use more debt, and the value of the levered firm will equal that of an un-levered firm plus the present value of tax shield provided by debt.

Miller (1977) modified the theory by introducing both corporate and personal taxes. He states that the firm has an incentive to use debt, and will continue to do that until its additional supply of debt drives up interest rates to the point where the tax advantages of interest deduction are completely offset by higher rates. This will be the point at which the marginal investor's personal tax equals the corporate tax rate. Additionally, the advantage from using debt is zero if the income tax rates for stocks and bonds are equal, and the firm's performance and value is independent of the method of financing.

According to Kraus \& Litzenberger (1973) static tradeoff theory affirms that firms have optimal capital structures which they determine by trading off the costs against the benefits of the use of debt and equity. The theory suggests that debt has a central role in firm financing. The firm substitute's debt for equity or equity for debt until the value of the firm is maximized. Static trade-off theory predicts a negative relation between a firm's growth opportunity and financial leverage ratio; because growth firms can incur much higher financial distress costs and lower agency costs of free cash flow. Among the benefits of the use of debt is the advantage of a debt tax shield. One of the disadvantages of debt is the cost of potential financial distress, especially 
when the firm relies on too much debt. This leads to a trade-off between the tax benefit and the disadvantage of higher risk of financial distress. But there are more cost and benefits involved with the use of debt and equity. One other major cost factor consists of agency costs. Jensen (1986) argues that debt is an efficient means by which to reduce the agency costs associated with equity. Agency costs stem from conflicts of interest between the different stakeholders of the firm and because of ex post asymmetric information Jensen and Meckling (1976).Hence, incorporating agency costs into the static trade-off theory means that a firm determines its capital structure by trading off the tax advantage of debt against the costs of financial distress of too much debt and the agency costs of debt against the agency cost of equity. Therefore, the prediction of the static trade-off theory is that firms target their capital structures.

Myers and Majluf (1984) indicated that a firm shows a distinct preference for using internal finance (as retained earnings or excess liquid assets) over external finance and debt to equity if the firm issues securities. If internal funds are not enough to finance investment opportunities, firms may or may not acquire external financing, and if they do, they will choose among the different external finance sources in such a way as to minimise additional costs of asymmetric information. The pecking order was traditionally explained by transaction and issuing costs. Retained earnings involve few transaction costs and issuing debt incurs lower transaction costs than equity issues. Debt financing also involves a tax reduction if the firm has a taxable profit. Myers and Majluf (1984) invoked asymmetric information to give a theoretical explanation for the pecking order phenomena. The signalling model showed that only low profit type firms would issue equity in a separating equilibrium. To avoid this discount, managers avoid equity whenever possible.

The agency theory for free cash flows by Jensen (1986) suggests that the use of debt can reduce the free cash flow available to managers and constrain or encourage them to act more in the interests of shareholders. Debt is used to control the managers' opportunistic behaviour by reducing the free cash flows in their hands. This will prevent the investment in negative projects by committing the management to pay fixed interest payments. The agency cost theory is premised on its preference for higher debt in financing when agency problem becomes pronounced.

The market timing theory of capital structure argues that managers look at current conditions in both debt and equity markets. If they need financing, they use whichever market currently looks more favourable (Boudry, Kallberg \& Liu, 2010).If neither market looks favourable, they may defer issuances. Alternatively, if current conditions look unusually favourable, funds may be raised even if the firm has no need for funds currently. Firms time their equity issues in the sense that they issue new stock when the stock price is perceived to be overvalued, and buy back own shares when there is undervaluation. Consequently, fluctuations in stock prices affect firm capital structure.
Companies are assumed to issue equity directly after a positive information release which reduces the asymmetry problem between the firm's Management and stockholders. The decrease in information asymmetry coincides with an increase in the stock price. In response, firms create their own timing opportunities. In a study by Graham and Harvey (2001) managers admitted trying to time the equity market, and most of those that have considered issuing common stock report that "the amount by which our stock is undervalued or over- valued" was an important consideration. Baker and Wurgler (2002) provide evidence that equity market timing has a persistent effect on the capital structure of the firm. They find that leverage changes are strongly and positively related to their market timing measure, so they conclude that the capital structure of a firm is the cumulative outcome of past attempts to time the equity market.

\subsection{Leverage}

Capital structure is the mix of debt (leverage) and equity capital used to finance a firm's operations (Ebaid, 2009).Leverage involves the use of fixed costs to magnify a firm's return (Pandey, 2005).Debt can be classified either as short term debts, long term debt or total debt. Generally increases in leverage results in increased return and risk, whereas decreases in leverage result in decreased return and risk (Imad, 2013). The debt level of different firms may be explained by the following factors.

\subsubsection{Firm Size}

Firm size can either be measured by level of assets or magnitude of sales. Firm size was measured by natural logarithm of total assets as used by (Onaolapo and Kajola, 2010). The trade-off theory suggest that larger firms should operate at high debt levels due to their ability to diversify the risk and to take the benefit of tax shields on interest payments. Large firms usually are more diversified and have lower variance in earnings and hence can accommodate high debt ratios. Smaller firms on the other hand may find it relatively more costly to incorporate debt in their operation. Thus larger firms will have higher debt levels than smaller firms. Empirical evidence on the relationship between size and capital structure supports a positive relationship. Al-Sakran (2001) suggested that smaller firms are likely to use equity finance while larger firms are likely to use debt.

\subsubsection{Growth Opportunity for Firm}

Growth opportunity for firm is an important determinant of firm capital structure. A good indicator for growth is related to the change in total sales or the total assets (Onaolapo and Kajola,2010)Static trade-off theory predicts a negative relation between a firm's growth opportunity and financial leverage ratio; because growth firms can incur much higher financial distress costs and lower agency costs of free cash flow. Therefore they tend to reduce their financial leverage. On the contrary, pecking order theory 
implies that firms with higher growth opportunities make more investments. To finance these investment projects, firms have to issue more debt. Thus the relation between a firm's growth opportunity and financial leverage ratio is positive. Firms with high growth opportunity tend to use equity financing rather than debt financing, since they do not want to pass up future profitable investment opportunities.

\subsubsection{Firm Liquidity}

A Firm's liquidity is the ability of the firm to meet its short-term obligations; it is defined as the ratio of current assets to current liability (Pandey, 2005). According to the free cash free theory, Firms with high liquidity may have high debt because of their ability to meet short-term liabilities which means a positive relationship between liquidity and debt level. Jensen and Meckling (1976) argued that managerial incentives to allocate the firm's resources to their private benefit are larger when the firm is mainly equity financed. Debt creation enables managers to effectively bond their promise to pay out future cash flows. According to the pecking-order theory, high liquidity firms have the choice to use their assets as an internal financing source instead of issuing debt to finance their projects. This indicates a negative relationship with debt (Khan, 2012). Firms with high liquidity may have high debt because of their ability to meet short-term liabilities.

\subsection{Firm Performance}

Firm performance is identified as one of the most important indicators of effect of capital structure in the review of literature. Performance is reflected by firm profitability that is affected by leverage. Higher profitability usually provides more internal financing and hence a lower level of debt by the firm (Abor, 2005). Less debt is then needed to finance already planned investments. Debt introduces an agency cost argument. Management will refrain from the building of empires and excessive consumption of perquisites, when large sums of money must be paid to creditors each year. High profitability results in higher leverage according to the free cash flow hypothesis, but a high leverage would result in high profitability on the basis of the pecking order hypothesis.

\subsection{Empirical Research on Leverage and Firm Performance}

Many researchers have investigated the relationship between leverage and firms performance for various industry sectors. The various researchers concluded both positive and negative association between the debt level and firm's performance.

\subsubsection{Negative Association of Leverage and Performance}

Studies that have established a negative association between financial leverage and return on equity are presented as follows:

Mwangi et al (2014) studied the relationship between capital structure and performance of non-financial companies listed in the Nairobi Securities Exchange in Kenya and concluded that increased financial leverage has a negative effect on performance.

Imad Z. R. (2013) investigated the debt-performance relation for 77 Jordanian industrial companies over the period between 2000 and 2011. The results of analysis show that debt structure expressed as: long-term debt, short-term debt, and total debt have a significantly negative relationship with Return on Assets.

Abbasali and Esfandiar (2012) investigated the impact of capital structure on the financial performance of companies listed in the Tehran Stock Exchange and tested a sample of 400 firm. They concluded that there was a significant negative relationship between debt ratio and financial performance of companies, and a significant positive relationship between asset turnover, firm size, asset tangibility ratio, and growth opportunities with financial performance measures.

Nima et al (2012) investigated the possible relationship between current debt, non-current debt, and total debt as proxies for capital structure, and the performance of Iranian companies listed at Tehran Stock Exchange. The study concluded that the proxies of the capital structure of the Iranian firms have a negative effect on the Iranians firm's performance.

Khan (2012) tested the impact of the debt structure on the firm's performance for the Pakistanian companies. The study concluded that the short term debt and total debt as proxies of debt structure have a significantly negative effect on the firm's return on assets, a proxy of the firm's performance.

Saeedi and Mahmoodi (2011) evaluated the association between capital structure and firm's profitability. Their result shows that firm's profitability measured by earnings per share and Tobin's Q, are positively affected by capital structure, whereas the Returns on Assets associated negatively with the capital structure, and no significant association between Returns on Equity and capital structure

Onaolapo and Kajola (2010) investigated the effect of capital structure on financial performance of companies listed on Nigeria Stock Exchange. This study was performed on 30 nonfinancial companies in 15 industry sectors in a 7-year period from 2001 to 2007. The results showed that the capital structure (debt ratio) has a significant negative effect on measures of financial performance of these companies.

Ebaid (2009) established a very weak relationship between the debt structure and the firm's performance for the Egyptian firms. The study concluded that the relation between the proxies of the debt structure and the ROE is insignificant. While the short term debt and total debt to total assets has a negative and statistically significant effect on the firm's ROA.

Zeitun and Tian (2007) surveyed the impact of capital structure on the firm performance for 167 Jordanian companies during 1989 to 2003 . The results suggest that 
capital structure has significantly negative impact on accounting measures of firm performance evaluation. Also they indicate that short-term debt to total assets ratio has significantly negative impact on market measure of Jordanian companies' performance evaluation.

Abor (2005) examined the relationship between capital structure and profitability of listed firms on the Ghana Stock Exchange for a five-year period. A negative relationship between the ratio of long-term debt to total assets and return on equity was found.

Sogorb (2005) surveyed the impact of small and medium company's features on their capital structure in Spain during 1994 to 1998 and used data of 6,482 nonfinancial companies in 8 industries. Results show that tax reserves and profitability of these companies have negative relationship with capital structure while size, growth opportunities and assets structure in these companies have positive relationship with capital structure.

Majumdar and Chhibber, (1999) examined the relationship between the levels of debt in the capital structure and performance for a sample of Indian firms. The conclusion from the analysis of the data indicated a significantly negative relationship between the levels of debt in the capital structure and performance for the Indian firm investigated.

Rajan and Zingales (1995) studied the determinant factors of capital structure of common company corporations in seven large countries around the world (America, Japan, Germany, France, Italy, Britain and Canada) during 1987 to 1991. In this study, they chose 4557 companies as samples of these seven countries. The findings indicated that financial leverage has negative relationship with profitability.

\subsubsection{Positive Association of Leverage and Performance}

Studies that establish a positive association between financial leverage and return on equity are presented as follows:

Zuraidah et al. (2012) explored the effect of the capital structure on firm's profitability by using ROA and ROE as proxies for the performance, and short-term debt, long-term debt and total debt as proxies for the capital structure. The study concluded that short-term debtand total debt have a significant association with ROA.

Aburub (2012) investigated the impact of capital structure on the firm performance of companies listed in Palestine Stock Exchange during 2006 to 2010 in which 28 companies were selected in the sample. In this study, five measures of Return On Equity, return on assets, earnings per share, market value to book value of equity ratio and Tobin $\mathrm{Q}$ ratio as the measures of accounting and market of firm performance evaluation and also as dependent variables and four measures of short-term debt to total assets ratio, long-term debt to total assets ratio, total debt to total assets ratio and total debt to total equity ratio as the measures of capital structure and also as the independent variables were selected. Results indicate that the capital structure has a positive effect on firm performance evaluation measures.

\subsection{Literature Review Summary}

The review of the foregoing literature indicates that the search for an optimal debt ratio that maximises shareholders' wealth is not yet conclusive. The researchers advocate for optimal debt and it therefore implies that firms have employed debt to various levels as captured by the debt equity ratio. The question as to whether various debt equity ratio levels lead to different financial performance when compared for high levered and low levered firm, high growth and low growth firm or large and small firms still remains unclear. Thus in attempt to fulfil this gap the researchers undertook to establish the how levered firms are affected by level of debts, growth opportunities and firm size as regards their financial performance in attempt to maximize shareholder's wealth.

\section{Methodology}

Causal research design was used to explain how the independent variable produces change in the dependent variable therefore determining the cause effect relationship that exists among variables, (Copper \& Schindler, 2006). Secondary data extracted from published reports related to equity, total assets, and level of debt, current assets and current liabilities that enabled compute variables for a period of 6 years. Tests for normality, homoskedasticity, multicolinearity and correlation were carried out on the data to prepare for analysis preparation. Firms with debt equity ratio above $20 \%$ were categorised as highly levered. High firms are those with higher than the average growth rate of $4.4 \%$ for the economy for the 6 years of study from 2008 to 2013. Large firms were considered as firms with asset in excess of Sh.10 billion. The value of firm size was normalised by logarithmic transformation of total assets.

The analysis model to determine the relationship between Growth, Firm size, liquidity and Return on equity for the 6 year period was formulated as follows:

$$
\mathrm{ROE}_{\mathrm{i}, \mathrm{t}}=\beta_{0}+\beta_{1} \mathrm{DE}_{\mathrm{it}}+\beta_{2} \mathrm{GR}_{\mathrm{it}}+\beta_{3} \mathrm{SZ}_{\mathrm{it}}+\beta_{4} \mathrm{LQ}_{\mathrm{it}}+\varepsilon_{\mathrm{it}}
$$

Where:

ROE $=$ Return on Equity

$\mathrm{DE}_{\mathrm{it}}=$ Debt Equity for firm $\mathrm{i}$ in time $\mathrm{t}$

$\mathrm{GR}_{\mathrm{it}}=$ Growth Opportunity for firm $\mathrm{i}$ in time $\mathrm{t}$

$\mathrm{SZ}_{\text {it }}=$ Firm Size for firm $\mathrm{i}$ in time $\mathrm{t}$

$\mathrm{LQ}_{\mathrm{it}}=$ Liquidity for firm $\mathrm{i}$ in time $\mathrm{t}$

$\beta_{0}=$ Regression constant

$\beta_{1}, \beta_{2}, \beta_{3}, \beta_{4}$, = regression coefficients

$\varepsilon_{\mathrm{it}}=$ the error term 


\section{Results and Discussions}

\subsection{Descriptive Statistics Analysis}

The descriptive statistics were analysed for the variables of the study.

Table 1. Descriptive Statistics.

\begin{tabular}{llllll}
\hline & Range & Min & Max & Mean & Std. Deviation \\
\hline ROE & 1.30 & -.70 & .60 & .12 & .19 \\
D/E & 1.60 & .00 & 1.60 & .43 & .44 \\
Growth Rate & .40 & -.10 & .30 & .079 & .087 \\
Ln Total Assets & 6.60 & 12.20 & 18.80 & 15.65 & 1.64 \\
Liquidity & 11.10 & .40 & 11.50 & 2.28 & 2.23 \\
\hline
\end{tabular}

The average financial leverage for sample was $43 \%$. The minimum ratio of financial leverage is nil indicating that some firms employed no debt in their capital structure, whereas the maximum value is $160 \%$ denoting that there is high variation in using financial leverage. With regard to return on equity, the average of return was $12 \%$ which is very low when compared with the $60 \%$ maximum return. It shows that some firms reported large losses and hence poor performance generally. The average growth rate for the firms is $7.9 \%$ which is higher than the $4.4 \%$ average GDP growth rate for Kenya. The size of the company measured by the natural logarithm of the total assets had a mean of 15.65 and a variability of 1.64 indicating that the data is concentrated around the mean and has less spread. The mean current ratio of 2.28 indicates that the companies have adequate liquidity that supports the high return on equity.

\subsection{Correlation}

Correlation coefficient was used to determine the strength and nature of linear relationship among the variables. The value of coefficient of correlation lies between -1 to +1 representing perfectly negative and perfectly positive correlation respectively.

Table 2. Correlation Matrix.

\begin{tabular}{|c|c|c|c|c|c|c|}
\hline & & ROE & $\mathbf{D} / \mathbf{E}$ & Growth Rate & Ln Total Assets & Liquidity \\
\hline ROE & $\begin{array}{l}\text { Pearson Correlation } \\
\text { Sig. (2-tailed) }\end{array}$ & 1 & & & & \\
\hline $\mathrm{D} / \mathrm{E}$ & $\begin{array}{l}\text { Pearson Correlation } \\
\text { Sig. (2-tailed) }\end{array}$ & $\begin{array}{l}-.203 \\
.222\end{array}$ & 1 & & & \\
\hline Growth Rate & $\begin{array}{l}\text { Pearson Correlation } \\
\text { Sig. (2-tailed) }\end{array}$ & $\begin{array}{l}.444^{* *} \\
.005\end{array}$ & $\begin{array}{l}.116 \\
.490\end{array}$ & 1 & & \\
\hline Ln Total Assets & $\begin{array}{l}\text { Pearson Correlation } \\
\text { Sig. (2-tailed) }\end{array}$ & $\begin{array}{l}.175 \\
.294\end{array}$ & $\begin{array}{l}.380^{*} \\
.018\end{array}$ & $\begin{array}{l}.066 \\
.694\end{array}$ & 1 & \\
\hline Liquidity & $\begin{array}{l}\text { Pearson Correlation } \\
\text { Sig. (2-tailed) }\end{array}$ & $\begin{array}{l}.275 \\
.095\end{array}$ & $\begin{array}{l}-.269 \\
.102\end{array}$ & $\begin{array}{l}.370^{*} \\
.022\end{array}$ & $\begin{array}{l}-.485^{* *} \\
.002\end{array}$ & 1 \\
\hline
\end{tabular}

The Pearson coefficient between return on equity and debt equity ratio is $\mathrm{r}=-0.203(\mathrm{P}$ value $=.222)$ and thus indicates a weak negative relationship between debt equity ratio and return on equity that was not significant. The Pearson coefficient between return on equity and growth rate is $r=$ 0.44 ( $\mathrm{P}$ value $=0.005)$ and therefore indicates moderately weak positive relationship between return on equity and growth rate that was weakly significant. Thus a growth opportunity enables firms to improve on return for equity holders. The Pearson coefficient between return on equity and firm size is $\mathrm{r}=0.175$ ( $\mathrm{P}$-value $=0.294$ ) and was not significant. This implies that firm size had a moderately weak positive relationship with return on equity.

\subsection{Testing Hypotheses}

$H O_{I}$ : There is no significant difference in financial performance between highly levered firms and low levered firms.

Firms with debt equity ratio above $20 \%$ were categorised as highly levered while the rest as low levered firms. This resulted in 26 firms classified as high leverage while 12 firms as low levered firms.

Table 3presents regression analysis results that show independent variables for low levered firms have higher power explanation of performance $\left(\mathrm{R}^{2}=0.51\right)$ compared with high levered firms. The results also indicate that the regression analysis for high and low levered firms is that financial leverage is associated negatively to firm performance. A $1 \%$ increase in debt equity ratio for high levered and low levered firms would reduce return on equity by $0.14 \%$ and $1.2 \%$ respectively. At $5 \%$ significant level (P value 0.188 and $0.70>0.05)$, we failed to reject the null hypothesis that $\mathrm{H}_{0}: \beta_{1 \mathrm{H}}=\beta_{1 \mathrm{~L}}=0$ implying that the coefficients for both high and low levered firms are insignificant. There is, therefore, no significant difference between financial performances for high levered and low levered firms. This is consistent with the pecking order theory of capital structure.

Table 3. Regression output of financial leverage of high and low levered firms.

\begin{tabular}{|c|c|c|c|c|c|c|}
\hline & \multicolumn{3}{|c|}{ High Levered firms } & \multicolumn{3}{|c|}{ Low levered firms } \\
\hline & \multicolumn{2}{|c|}{$\begin{array}{l}\text { Unstandardized } \\
\text { Coefficients }\end{array}$} & \multirow[t]{2}{*}{ Sig. } & \multicolumn{2}{|c|}{$\begin{array}{l}\text { Unstandardized } \\
\text { Coefficients }\end{array}$} & \multirow[t]{2}{*}{ Sig. } \\
\hline & $\beta_{1 \mathrm{H}}$ & Std. Error & & $\beta_{1 L}$ & Std. Error & \\
\hline (Constant) & -.818 & .450 & .084 & -.356 & .344 & .341 \\
\hline $\mathrm{D} / \mathrm{E}$ & -.140 & .103 & .188 & -1.209 & .549 & .070 \\
\hline Growth Rate & .734 & .501 & .159 & 0.241 & .416 & .584 \\
\hline Total Assets log & .063 & .029 & .042 & .033 & .023 & .206 \\
\hline Liquidity & .031 & .023 & .196 & .020 & .014 & .202 \\
\hline R Square & .44 & 0.187 & & .510 & .738 & \\
\hline F & 3.14 & & 0.03 & 1.249 & & 0.39 \\
\hline Observations & 26 & & & 12 & & \\
\hline
\end{tabular}

Dependent Variable: ROE 
$\mathrm{HO}_{2}$ : There is no significant difference in financial performance between high growth levered firms and low growth levered firms.

Theaverage GDP growth rate for Kenya for the 6 years of study was used to categorize firms on the basis of growth.

The average GDP growth rate during this period was $4.4 \%$ and this resulted in 27 firm classified as high growth firms and 11 firms as low growth firms.

Table 4. Regression output of growth rate differences on the firms' performance.

\begin{tabular}{|c|c|c|c|c|c|c|}
\hline & \multicolumn{3}{|c|}{ High growth firms } & \multicolumn{3}{|c|}{ Low growth firms } \\
\hline & \multicolumn{2}{|c|}{$\begin{array}{l}\text { Unstandardize } \\
\text { d Coefficients }\end{array}$} & \multirow{2}{*}{ Sig. } & \multicolumn{2}{|c|}{$\begin{array}{l}\text { Unstandardized } \\
\text { Coefficients }\end{array}$} & \multirow{2}{*}{ Sig. } \\
\hline & $\boldsymbol{\beta}_{2 \mathrm{H}}$ & $\begin{array}{l}\text { Std. } \\
\text { Error }\end{array}$ & & $\boldsymbol{\beta}_{2 L}$ & $\begin{array}{l}\text { Std. } \\
\text { Error }\end{array}$ & \\
\hline Constant & -.143 & .368 & .701 & .644 & 1.159 & .602 \\
\hline $\mathrm{D} / \mathrm{E}$ & .004 & .075 & .963 & -.443 & .568 & .471 \\
\hline Growth Rate & .078 & .457 & .865 & 5.052 & 2.889 & .141 \\
\hline Total Asset log & .024 & .024 & .324 & -.034 & .069 & .646 \\
\hline Liquidity & .021 & .015 & .177 & -.039 & .086 & .672 \\
\hline R Square & .153 & .137 & & .80 & .1692 & \\
\hline $\mathrm{F}$ & .758 & & .590 & 4.00 & & .770 \\
\hline Observations & 27 & & & 11 & & \\
\hline
\end{tabular}

a. Dependent Variable: ROE

Table 4 indicates that performance for high growth firms was positively related to debt though insignificant. However, Low growth firms performance was negatively related to debt though insignificant. The null hypothesis that $\mathrm{H}_{0}: \beta_{2 \mathrm{H}}=\beta_{2 \mathrm{~L}}=0$ was accepted implying that the coefficients for both high and low levered firms were insignificant ( $P$ value .963 and $.471>0.05)$. This implies that there is no significant difference between performance of levered high growth firm and low growth firms. This finding is consistent with the Static trade-off theory that indicates a negative relation between a firm's growth opportunity and financial leverage ratio; because growth firms tend to balance incurring much higher financial distress costs and lower agency costs of free cash flow and therefore tend to reduce their financial leverage.Mwangi et al (2014), Abbasali P and Esfandiar M (2012) and Rajan and Zingales (1995); results are consistent that growth is negatively related to debt.

$\mathrm{HO}_{3}$ : There is no significant difference in financial performance between large levered firms and small levered firms on the firm performance.

Firm sizes were categorized as large or small by considering the level of firm assets. Large firms were considered as firms with asset in excess of Sh.5 billion and the size was measured by natural logarithm of total assets. 21 firms were classified as large and 17 as small firms.

Table 5 indicates that the financial performance for both large and small firms was negatively related to debt ratio though insignificant. The null hypothesis that $\mathrm{H}_{0}: \beta_{3 \mathrm{~L}}=\beta_{3 \mathrm{~S}}=0$ was accepted implying that the regression coefficients for both large and small firms are insignificant ( $P$ value 0.459 and $0.225>0.05)$. Therefore there is no significance difference in financial performance between large levered and small levered firms and that performance was positively related to leverage for both large and small firm though insignificant.

Table 5. Regression output of firms'size on performance of firms.

\begin{tabular}{|c|c|c|c|c|c|c|}
\hline & \multirow{2}{*}{\multicolumn{2}{|c|}{$\begin{array}{l}\text { Large firms } \\
\text { Coefficients }\end{array}$}} & \multirow[b]{3}{*}{ Sig. } & \multicolumn{3}{|c|}{ Small firm } \\
\hline & & & & \multicolumn{2}{|c|}{ Coefficients } & \multirow[b]{2}{*}{ Sig. } \\
\hline & $\beta_{3 L}$ & $\begin{array}{l}\text { Std. } \\
\text { Error }\end{array}$ & & $\beta_{3 \mathrm{~s}}$ & $\begin{array}{l}\text { Std. } \\
\text { Error }\end{array}$ & \\
\hline (Constant) & .616 & .810 & .459 & -1.040 & .809 & .225 \\
\hline $\mathrm{D} / \mathrm{E}$ & -.024 & .098 & .808 & -.347 & .187 & .091 \\
\hline Growth Rate & .066 & .565 & .908 & .988 & .503 & .075 \\
\hline Total Asset log & -.022 & .047 & .653 & .077 & .054 & .181 \\
\hline Liquidity & -.059 & .076 & .452 & .019 & .018 & .323 \\
\hline R Square & .052 & .158 & & .701 & .154 & \\
\hline $\mathrm{F}$ & .164 & & .972 & 5.161 & & .011 \\
\hline Observations & 21 & & & 17 & & \\
\hline
\end{tabular}

a. Dependent Variable: ROE

\section{Findings and Conclusions}

The study found that there was no significant difference in financial performance between high levered and low levered firms. It was also found out that there existed a negative relationship between Leverage and firm's performance, findings that were consistent with findings by Mwangi et al.(2014), Imad Z. R. (2013), Abbasali P. et al (2012), Frank and Goyal (2003) and Nima et al (2012). The study also found that there were no significance differences in financial performance between the high growth levered firms and low growth levered firms and that there existed a negative relation between a firm's growth opportunity and financial leverage ratio. The growth rate for both high levered and low levered firms is insignificant to the financial performance. There were also no significance difference in financial performance between large levered firms and levered small firms. The results also show that performance is positively related to leverage for both large and small firm but was insignificant.Firms should prefer internal finance over external finance to increase return to shareholders since financial performance is negatively related to debt. Firms should also seek to maintain a target debt level consistent with trade-off theory or to follow a financing hierarchy consistent with pecking order theory in order to improve on financial performance.

\section{References}

[1] Abbasali P \& Esfandiar M (2012). The Relationship between Capital Structure and Firm Performance Evaluation Measures: Evidence from the Tehran Stock Exchange, International Journal of Business and Commerce Vol. 1, No. 9 ,166-181

[2] Abor,J. (2005). "The effect of capital structure on profitability: an empirical analysis of listed firms in Ghana", Journal of Risk Finance, 6, pp. 438-47

[3] Aburub, N. (2012). Capital Structure and Firm Performance: Evidence from Palestine Stock Exchange. Journal of Money, Investment and Banking, 23, 109-117. 
[4] Amara and Bilal Aziz, (2014). Impact of Capital Structure on Firm Performance: Analysis of Food Sector Listed on Karachi Stock Exchange, International Journal of Multidisciplinary Consortium, Volume - $1 \mid$ Issue - 1

[5] Baker, M. and J. Wurgler, (2002). Market Timing and Capital Structure, Journal of Finance 57, 1-32

[6] Boudry, W, Kallberg, J \& Liu, C (2010). 'An analysis of REIT security issuance decisions', Real Estate Economic, vol. 38, no. 1 , pp. $91-120$.

[7] Cooper, R.D. and Schindler, S.P (2003). Business Research Methods, McGrawHill-Irwin

[8] Ebaid, I. E. (2009). The impact of capital-structure choice on firm performance: empirical evidence from Egypt, The Journal of Risk Finance, Vol. 10 No. 5, pp. 477-487

[9] Graham, J.R. and C. Harvey. (2001). The Theory and Practice of Corporate Finance: Evidence from the Field," Journal of Financial Economics 60, 187-243.

[10] Gitman, L. J. (2009). Principles of managerial finance. $12^{\text {th }}$ edition. Addison Wesley Prentice Hall

[11] Imad Z.R. (2013). Debt-Performance Relation. Evidence from Jordan International Journal of Academic Research in Accounting, Finance and Management Sciences, Vol. 3 (1), pp. 323-331

[12] Jensen, M.C. (1986). Agency Costs of Free Cash Flow, Corporate Finance, and Takeovers, American Economic Review 76, 323-329.

[13] Jensen, M. C. \& Meckling, W. H. (1976). The theory of the firm: managerial behaviour, agency costs and ownership structure, Journal of Financial Economics, vol. 3, no. 4, pp. 305-360.

[14] Khan, Abdul Ghafoor (2012). The relationship of capital structure decisions with firm performance: A study of the engineering sector of Pakistan, International Journal of Accounting and Financial Reporting, Vol. 2, No. 1, pp. 245262 .

[15] Kraus, A. \& Litzenberger, R. H. (1973). A State-Preference Model of Optimal Financial Leverage , Journal of Finance, vol. 28 , no. 4, pp. 911-922.

[16] Majumdar, S. K., \& Chhibber, P. (1999). Capital structure and performance: Evidence from a transition economy on an aspect of corporate governance.
[17] Modigliani, F. and M.H. Miller (1958). The Cost of Capital, Corporate Finance and the Theory of Investment. The American Economic Review, Vol.48, No.3, June 1958.

[18] Modigliani, F. and Miller, M. (1963).Corporate Income Taxes and the Cost of Capital: a Correction, the American Economic Review, 53: 443-53.

[19] Muritala, T. A. (2012). An Empirical Analysis of Capital Structure on Firms Performance in Nigeria, International Journal of Advances in Management and Economics. 1 116124.

[20] Murray Z. Frank and Vidhan K. Goyal (2007). Capital Structure Decisions: Which Factors are Reliably Important? Financial Management, Vol. 38, No. 1 (spring, 2009), pp. 1-37

[21] Mwangi, L.M, Makau, M.S \& Kosimbei, G (2014). The relationship between Capital Structure and Performance of Non-Financial Companies Listed in the Nairobi Securities Exchange, Kenya". Global Journal of Contemporary Research in Accounting, Auditing and Business Ethics, Vol: 1 Issue 2.

[22] Myers, S. C. (1984). The capital structure puzzle: Journal of Finance, 39, 575- 592

[23] Onaolapo, A.A., \& Kajola, S.O. (2010). Capital Structure and Firm Performance: Evidence from Nigeria. European Journal of Economics, Finance and Administrative Sciences, 25, 7082.

[24] Pandey, I. (2005). Financial Management. New Delhi: Vikas Publishing House

[25] Rajan, R.G., \& Zingales, L. (1995). What do We Know about Capital Structure? The Journal of Finance, 50(5), 1421-1460.

[26] Saeedi,A and Mahmoodi, (2011).Capital Structure and Firm Performance: Evidence from Iranian Companies, International Research Journal of Finance and Economics, issue 70

[27] Sogorb, F. (2005). How SME Uniqueness Affects Capital Structure: Evidence a 1994-1998 Spanish data panel. Small business economics, 25(5), 447-457

[28] Zeitun, R and Tian, G. (2007).Capital structure and corporate performance: evidence from Jordan. The Australasian Accounting Business \& Finance Journal, 1(4), 40-61.

[29] Zuraidah Ahmad, Norhasniza Mohd Hasan Abdullah, and Shashazrina Roslan (2012). Capital Structure Effect on Firms Performance: Focusing on Consumers and Industrials Sectors on Malaysian Firms. International Review of Business Research Papers Vol. 8. No.5. pp. 137 - 155. 